\title{
Overview and Perspectives for Vehicle-Integrated Photovoltaics
}

\author{
Benjamin Commault *(1), Tatiana Duigou, Victor Maneval, Julien Gaume, Fabien Chabuel and Eszter Voroshazi
}

Univ. Grenoble Alpes, CEA, Liten, INES, ITE INES.2S, 73375 Le Bourget du Lac, France; tatiana.duigou@cea.fr (T.D.); Victor.maneval@ntnu.no (V.M.); julien.gaume@cea.fr (J.G.); fabien.chabuel@cea.fr (F.C.); eszter.voroshazi@cea.fr (E.V.)

* Correspondence: benjamin.commault@cea.fr

check for updates

Citation: Commault, B.; Duigou, T.; Maneval, V.; Gaume, J.; Chabuel, F.; Voroshazi, E. Overview and Perspectives for Vehicle-Integrated Photovoltaics. Appl. Sci. 2021, 11, 11598. https://doi.org/10.3390/ app112411598

Academic Editor: Manuela Sechilariu

Received: 8 October 2021

Accepted: 18 November 2021

Published: 7 December 2021

Publisher's Note: MDPI stays neutral with regard to jurisdictional claims in published maps and institutional affiliations.

Copyright: (c) 2021 by the authors. Licensee MDPI, Basel, Switzerland. This article is an open access article distributed under the terms and conditions of the Creative Commons Attribution (CC BY) license (https:// creativecommons.org/licenses/by/ $4.0 /)$.

\begin{abstract}
On-board photovoltaic (PV) energy generation is starting to be deployed in a variety of vehicles while still discussing its benefits. Integration requirements vary greatly for the different vehicles. Numerous types of PV cells and modules technologies are ready or under development to meet the challenges of this demanding sector. A comprehensive review of fast-changing vehicleintegrated photovoltaic (VIPV) products and lightweight PV cell and module technologies adapted for integration into electric vehicles (EVs) is presented in this paper. The number of VIPV projects and/or products is on a steady rise, especially car-based PV integration. Our analysis differentiates projects according to their development stage and technical solutions. The advantages and drawbacks of various PV cell and module technologies are discussed, in addition to recommendations for widescale deployment of the technologies.
\end{abstract}

Keywords: photovoltaic; vehicle-integrated photovoltaics; curved PV; flexible PV; light PV

\section{Introduction}

The transport sector is one of the main contributors to the emissions of greenhouse gases (close to $25 \%$ in Europe). One solution is the electrification of transport via electrical vehicles. However, electric vehicles have limitations despite their purchase price such as limited autonomy and long or frequent recharge times. Vehicle-integrated photovoltaics may help mitigate these downsides. Electrical vehicle-integrated photovoltaics has untapped potential [1] and could accelerate mutual development. On-board photovoltaic energy generation is driven by technological, environmental, and legislative motivations. Among the promises are added range, fewer charging sessions, and a reduced carbon impact. Hybrid electric vehicles (HEV) and plug-in hybrid electric vehicles (PHEV) may also gain reduced $\mathrm{CO}_{2}$ emissions as eco-innovation [2] in the future with on-board photovoltaic energy generation.

The integration of photovoltaics into vehicles requires aesthetic, low-weight, and curved modules unlike standard modules used for utility application. Of course, other key metrics such as performance $\left(\mathrm{Wp} / \mathrm{m}^{2}\right)$, reliability, and safety are still applicable. Materials and technologies should remain cost-competitive to enable large-scale production. In addition to the significant technology change, another drawback is the lack of standards in the field of energy yield calculation from on-board photovoltaics, as well as adapted automotive and photovoltaic standards $[3,4]$.

This paper reviews the state of the art in terms of VIPV performance and available cell and module technologies, as well as module materials to meet the stringent weight and flexibility demands. Firstly, the status of commercial offers and research and development (R\&D) projects involving vehicles with on-board PV is presented. Secondly, current flexible and lightweight PV technologies are reviewed, and their potential for integration into EVs is discussed. Nonintegrated PV solutions are outside the scope of this paper. 


\section{Results and Discussions}

2.1. Review of Market Offers and RED Demonstrators Involving Vehicles with Integrated Photovoltaics (VIPV)

2.1.1. Overall View of the Market Offers and R\&D Demonstrators

Commercially available offerings and R\&D demonstrators of embedded photovoltaics are found on a variety of vehicle types such as private cars, camper vans, trains, trucks, passenger ships, planes, or spatial vehicles. Some examples of these vehicles (proof-ofconcept, prototype, or commercial vehicles) [5-17] are shown in Figure 1.

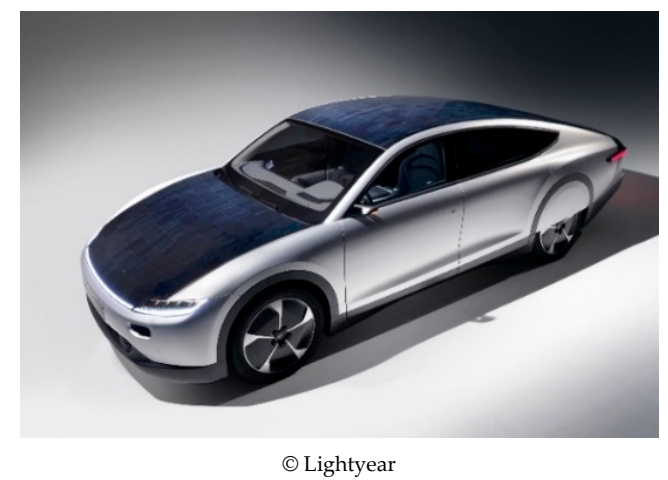

(a)

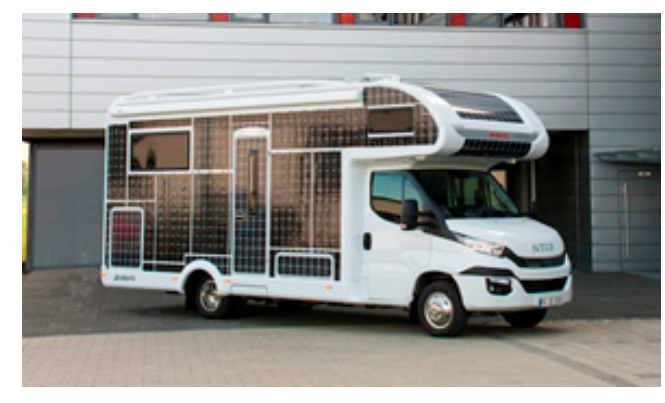

(ㄷ) Dethleffs

(c)

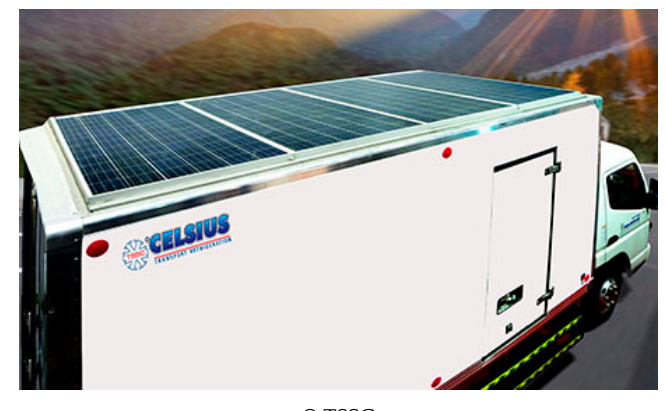

(e)

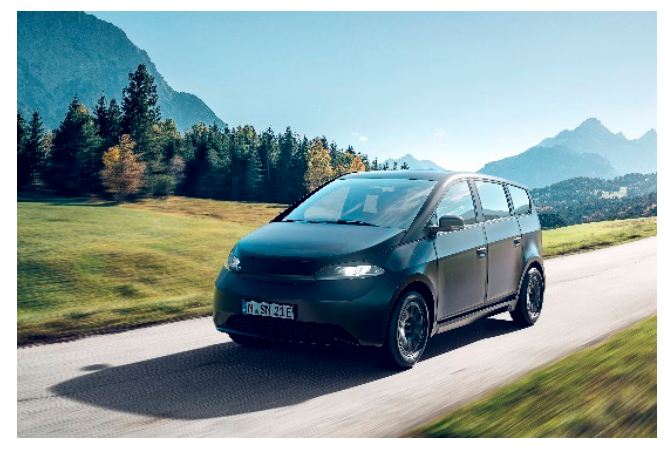

(c) Sono Motors

(b)

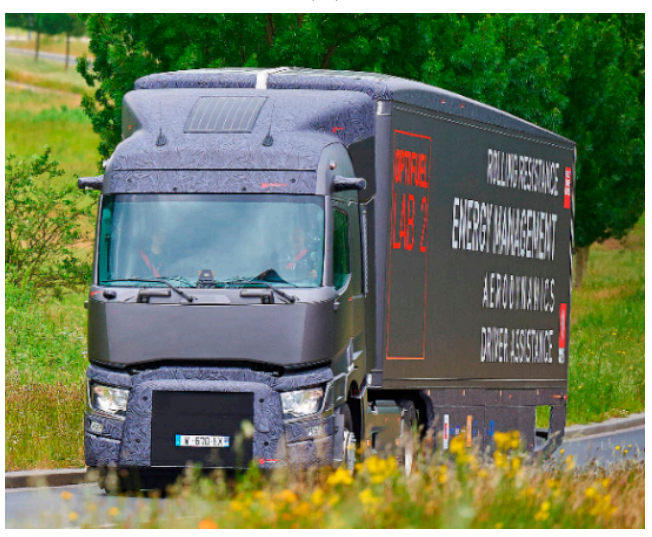

(C) Renault Trucks

(d)

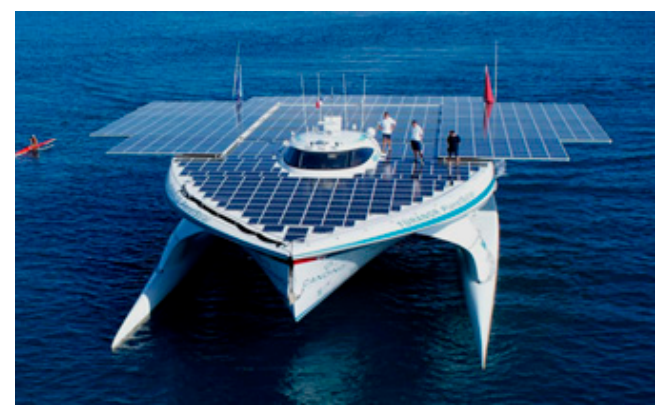

(C) @foundationPlanetSolar

(f)

Figure 1. Cont. 


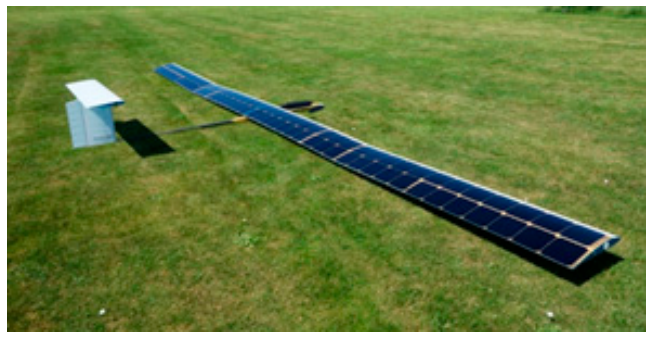

(c) Atlantik Solar

(g)

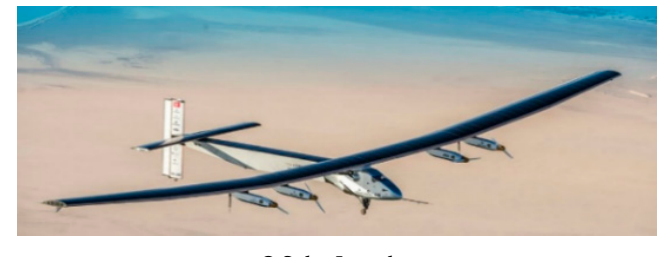

(c) Solar Impulse

(h)

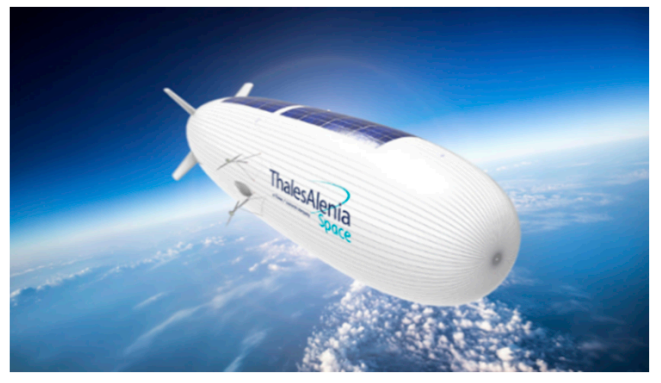

(c) Thales Alenia Space

(i)

Figure 1. (a) Proof of concept of the Lightyear One car [5]; (b) a car prototype-Sion from Sonomotors [6]; (c) Dethleffs motorhome demonstrator: E-home [8]; (d) a concept truck from Renault Truck—Optifuel Lab 2 [11]; (e) a set for freezer vehicles-TSSC S-Series [12]; (f) a ship proof of concept-Tûranor form PlanetSolar [13]; (g) a drone prototype from Atlantik Solar [14]; (h) a plane proof of concept-Solar Impulse [15]; (i) a spatial vehicle prototype: Stratobus [17].

A thorough list of VIPV commercial offerings and R\&D projects is shown in Table 1, including information such as module efficiency, cell technology, PV surface or power, model, manufacturer, and use of the PV-generated electricity.

Table 1. Noncomprehensive chart of VIPV products and R\&D initiatives.

\begin{tabular}{|c|c|c|c|c|c|c|c|c|c|c|}
\hline Type & Manufacturer & Model/Project & Stage & Year & $\begin{array}{l}\text { Vehicule } \\
\text { Weight }(t)\end{array}$ & $\begin{array}{l}\text { PV Surface } \\
\left(\mathrm{m}^{2}\right)\end{array}$ & $\begin{array}{c}\text { PV } \\
\text { Power } \\
\text { (kWp) }\end{array}$ & $\begin{array}{l}\text { Cell Technol- } \\
\text { ogy/Efficiency }\end{array}$ & PV Use & References \\
\hline Ship & Eco Ship & & Development & 2020 & & 12,000 & 750 & & Aux. & [18] \\
\hline Ship & Planet Solar & Tûranor & $\begin{array}{l}\text { Proof of } \\
\text { concept }\end{array}$ & 2010 & 89 & 516.0 & 93.5 & Silicon (Si) & $\begin{array}{l}\text { Prop. + } \\
\text { Aux. }\end{array}$ & [13] \\
\hline Ship & $\begin{array}{c}\text { Energy } \\
\text { Observer }\end{array}$ & $\begin{array}{c}\text { Energy } \\
\text { Observer }\end{array}$ & $\begin{array}{l}\text { Proof of } \\
\text { concept }\end{array}$ & 2017 & 28 & 130.0 & 21 & Silicon & $\begin{array}{l}\text { Prop. + } \\
\text { Aux. }\end{array}$ & [19] \\
\hline Ship & SoelCat & Catamaran 12 & $\begin{array}{l}\text { Proof of } \\
\text { concept }\end{array}$ & 2017 & 6 & & 8.6 & & $\begin{array}{l}\text { Prop. + } \\
\text { Aux. }\end{array}$ & [20] \\
\hline Bus & $\begin{array}{c}\text { Fast Concept } \\
\text { Car }\end{array}$ & Starter & $\begin{array}{l}\text { Proof of } \\
\text { concept }\end{array}$ & & & 20.5 & 3.4 & $\begin{array}{c}\text { Si mono } \\
\text { IBC } / 21.8 \%\end{array}$ & Aux. & [10] \\
\hline $\begin{array}{l}\text { Camper } \\
\text { Van }\end{array}$ & Dethleffs & E-home & $\begin{array}{l}\text { Proof of } \\
\text { concept }\end{array}$ & 2017 & 5.6 & 31.0 & 3 & Silicon mono & $\begin{array}{l}\text { Prop. + } \\
\text { Aux. }\end{array}$ & {$[8,21]$} \\
\hline Car & Hyundai & $\begin{array}{l}\text { Sonata } \\
\text { Hybrid } \\
\end{array}$ & Commercial & 2020 & & 1.3 & 0.204 & Si mono/22.8\% & $\begin{array}{l}\text { Prop. + } \\
\text { Aux. }\end{array}$ & {$[22,23]$} \\
\hline Car & Skoda & Superb & Commercial & 2000 & & & & & Aux. & [24] \\
\hline Car & Gaia & Wiseman & Commercial & & 0.8 & & 0.23 & $\begin{array}{c}\text { Silicon mono } \\
\text { IBC } \\
\end{array}$ & & [25] \\
\hline Car & Audi & $\mathrm{A} 8, \mathrm{~A} 6, \mathrm{~A} 4$ & Commercial & 1994 & & & 0.04 & & Aux. & [24] \\
\hline Car & Volkswagen & $\begin{array}{l}\text { Touareg, } \\
\text { Phaeton, } \\
\text { Passat }\end{array}$ & Commercial & 1994 & & & 0.04 & & Aux. & [24] \\
\hline Car & Mercedes & $\begin{array}{c}\text { E class, } \\
\text { Maybach }\end{array}$ & Commercial & 1994 & & & 0.04 & & Aux. & [24] \\
\hline Car & Nissan & $\begin{array}{c}\text { Leaf-SL } \\
\text { model }\end{array}$ & Commercial & 2014 & & & & & Aux. & [26] \\
\hline
\end{tabular}


Table 1. Cont.

\begin{tabular}{|c|c|c|c|c|c|c|c|c|c|c|}
\hline Type & Manufacturer & Model/Project & Stage & Year & $\begin{array}{l}\text { Vehicule } \\
\text { Weight (t) }\end{array}$ & $\begin{array}{c}\text { PV Surface } \\
\left(\mathrm{m}^{2}\right)\end{array}$ & $\begin{array}{c}\text { PV } \\
\text { Power } \\
(\mathbf{k W p})\end{array}$ & $\begin{array}{l}\text { Cell Technol- } \\
\text { ogy/Efficiency }\end{array}$ & PV Use & References \\
\hline Car & Toyota & $\begin{array}{c}\text { Toyota- } \\
\text { Prius } \\
\text { IV }\end{array}$ & Commercial & 2017 & 1.5 & 0.9 & 0.18 & HIT & Prop. & [7] \\
\hline Car & Karma & $\begin{array}{c}\text { Karma- } \\
\text { Revero }\end{array}$ & Commercial & 2017 & 2.5 & & 0.2 & & Prop. & [24] \\
\hline Car & Karma & Fisker & Commercial & 2011 & & & 0.12 & Silicon mono & & {$[24]$} \\
\hline Car & Hyundai/Kia & & Development & 2018 & & & & & & {$[27,28]$} \\
\hline Car & Tesla & CyberTruck & Development & 2019 & & & & & Prop. & [29] \\
\hline Car & Fiat & Phylla & Development & 2008 & 0.75 & & 0.34 & & Prop. & {$[30,31]$} \\
\hline Car & Toyota & Prius Prime & $\begin{array}{l}\text { Proof of } \\
\text { concept }\end{array}$ & 2019 & & & 0.86 & $\begin{array}{l}\text { Triple junction } \\
\text { cells } / 34.0 \%\end{array}$ & Prop. & [32] \\
\hline Car & Gazelle Tech & Gazelle & $\begin{array}{l}\text { Proof of } \\
\text { concept }\end{array}$ & 2020 & 0.68 & 4.0 & & ASCA modules & Prop. & {$[33,34]$} \\
\hline Car & SonoMotors & $\begin{array}{c}\text { Sono } \\
\text { Motors-Sion }\end{array}$ & $\begin{array}{l}\text { Proof of } \\
\text { concept }\end{array}$ & 2018 & 1.4 & 7.5 & 1.2 & $\begin{array}{l}\text { Si mono } \\
\text { IBC } / 24.0 \%\end{array}$ & Prop. & [6] \\
\hline Car & Hanergy & $\begin{array}{l}\text { Hanergy- } \\
\text { Solar R, O, L, } \\
\text { and A }\end{array}$ & $\begin{array}{l}\text { Proof of } \\
\text { concept }\end{array}$ & 2019 & 2 & 3.5 to 7.5 & 1 to 2 & $\begin{array}{c}\text { GaAs, III-V } \\
\text { flexible } / 29.0 \%\end{array}$ & Prop. & {$[35,36]$} \\
\hline Car & Ford & C-Max & $\begin{array}{l}\text { Proof of } \\
\text { concept }\end{array}$ & 2014 & & 1.5 & 0.3 & $\begin{array}{l}\text { Silicon mono } \\
\text { IBC }\end{array}$ & Prop. & [37] \\
\hline Car & $\begin{array}{l}\text { Bochum } \\
\text { Univ. }\end{array}$ & Solar racers & $\begin{array}{l}\text { Proof of } \\
\text { concept }\end{array}$ & $\begin{array}{l}2004- \\
2017\end{array}$ & $0.25-0.36$ & & 1.2 & $\begin{array}{l}\text { Silicon mono } \\
\text { IBC }\end{array}$ & Prop. & {$[38]$} \\
\hline Car & UNSW & $\begin{array}{l}\text { Sunswift } \\
\text { solar racers }\end{array}$ & $\begin{array}{l}\text { Proof of } \\
\text { concept }\end{array}$ & $\begin{array}{l}1994- \\
2017\end{array}$ & $0.17-0.43$ & $4.0-7.9$ & $0.8-1.8$ & $\begin{array}{l}\text { Silicon mono } \\
\text { IBC } / 18-23 \%\end{array}$ & Prop. & [39] \\
\hline Car & Audi & e-tron quattro & $\begin{array}{l}\text { Proof of } \\
\text { concept }\end{array}$ & 2015 & & 2.5 & 0.4 & & & [24] \\
\hline Car & Venturi & Eclectic & $\begin{array}{l}\text { Proof of } \\
\text { concept }\end{array}$ & 2006 & 0.35 & 2.5 & & & Prop. & [40] \\
\hline Car & Lightyear & One & $\begin{array}{l}\text { Proof of } \\
\text { concept }\end{array}$ & 2019 & 2 & 4.0 & & & Prop. & [5] \\
\hline Car & Volkswagen & Tiguan GTE & $\begin{array}{l}\text { Proof of } \\
\text { concept }\end{array}$ & 2015 & & 2.1 & 0.11 & & & [41] \\
\hline Car & ISRO & & $\begin{array}{l}\text { Proof of } \\
\text { concept }\end{array}$ & 2017 & & & & & Prop. & [42] \\
\hline Car & Peugeot & BB1 & $\begin{array}{l}\text { Proof of } \\
\text { concept }\end{array}$ & 2009 & & & & $16.0 \%$ & Aux. & [43] \\
\hline Drone & Atlantik Solar & & $\begin{array}{l}\text { Proof of } \\
\text { concept }\end{array}$ & 2017 & & & & $\begin{array}{l}\text { Si mono } \\
\text { IBC } / 23.0 \%\end{array}$ & Prop. & [14] \\
\hline Drone & NASA & Helios & $\begin{array}{l}\text { Proof of } \\
\text { concept }\end{array}$ & $\begin{array}{l}2001- \\
2003\end{array}$ & 0.8 & 180.0 & 35 & & $\begin{array}{l}\text { Prop. + } \\
\text { Aux. }\end{array}$ & [44] \\
\hline Drone & Airbus DS & Zephyr & $\begin{array}{l}\text { Proof of } \\
\text { concept }\end{array}$ & 2008 & 0.05 & & & & $\begin{array}{l}\text { Prop. }+ \\
\text { Aux. }\end{array}$ & [45] \\
\hline Plane & Solar Stratos & Solar Stratos & $\begin{array}{l}\text { Proof of } \\
\text { concept }\end{array}$ & 2014 & 0.45 & 22.0 & & $\begin{array}{c}\text { Si mono } \\
\text { IBC } / 22.0 \%\end{array}$ & $\begin{array}{l}\text { Prop. + } \\
\text { Aux. }\end{array}$ & [46] \\
\hline Plane & Océan Vital & Eraole & $\begin{array}{l}\text { Proof of } \\
\text { concept }\end{array}$ & 2015 & 0.75 & & 5.5 & $\begin{array}{l}\text { Si mono } \\
\text { IBC } / 24.0 \%\end{array}$ & $\begin{array}{l}\text { Prop. }+ \\
\text { Aux. }\end{array}$ & {$[16,47]$} \\
\hline Plane & & Solar Ship & $\begin{array}{l}\text { Proof of } \\
\text { concept }\end{array}$ & 2014 & & & & & Prop. & [48] \\
\hline Plane & Solar Impulse & Solar Impulse & $\begin{array}{l}\text { Proof of } \\
\text { concept }\end{array}$ & 2004 & 2.3 & 270.0 & & $\begin{array}{l}\text { Si mono } \\
\text { IBC } / 22.6 \%\end{array}$ & $\begin{array}{l}\text { Prop. }+ \\
\text { Aux. }\end{array}$ & [15] \\
\hline Spatial & Stratobus & Stratobus & $\begin{array}{l}\text { Proof of } \\
\text { concept }\end{array}$ & 2018 & & & & $\begin{array}{l}\text { Si mono } \\
\text { IBC } / 24.0 \%\end{array}$ & $\begin{array}{l}\text { Prop. + } \\
\text { Aux. }\end{array}$ & [17] \\
\hline Bus & FlixBus & & $\begin{array}{l}\text { Proof of } \\
\text { concept }\end{array}$ & 2020 & & & & CIGS & & [49] \\
\hline Train & India & & $\begin{array}{l}\text { Proof of } \\
\text { concept }\end{array}$ & 2017 & & & & $\mathrm{Si}$ & Aux. & [50] \\
\hline Train & SNCF & TER & $\begin{array}{l}\text { Proof of } \\
\text { concept }\end{array}$ & 2010 & & 23.0 & 3.1 & $\begin{array}{c}\text { Si mono } \\
\text { IBC } / 21.0 \%\end{array}$ & Aux. & [9] \\
\hline
\end{tabular}


Table 1. Cont.

\begin{tabular}{|c|c|c|c|c|c|c|c|c|c|c|}
\hline Type & Manufacturer & Model/Project & Stage & Year & $\begin{array}{c}\text { Vehicule } \\
\text { Weight (t) }\end{array}$ & $\begin{array}{l}\text { PV Surface } \\
\left(\mathrm{m}^{2}\right)\end{array}$ & $\begin{array}{c}\text { PV } \\
\text { Power } \\
\text { (kWp) }\end{array}$ & $\begin{array}{l}\text { Cell Technol- } \\
\text { ogy/Efficiency }\end{array}$ & PV Use & References \\
\hline Train & Byron Bay & & $\begin{array}{l}\text { Proof of } \\
\text { concept }\end{array}$ & & & & 6.5 & $\mathrm{Si}$ & Prop. & [51] \\
\hline Truck & TSSC & TSSC & Commercial & & & 6.4 & 1.2 & $\mathrm{Si}$ & Aux. & [12] \\
\hline Truck & Volvo & $\begin{array}{l}\text { SuperTruck } \\
\text { Cab }\end{array}$ & $\begin{array}{l}\text { Proof of } \\
\text { concept }\end{array}$ & 2014 & & & 0.27 & & Aux. & {$[24,52]$} \\
\hline Truck & Renault & $\begin{array}{c}\text { Optifuel Lab } \\
2\end{array}$ & $\begin{array}{l}\text { Proof of } \\
\text { concept }\end{array}$ & 2014 & & 31.1 & 4.6 & $\begin{array}{c}\text { Si mono } \\
\text { IBC } / 22.0 \%\end{array}$ & Aux. & [11] \\
\hline Truck & $\begin{array}{c}\text { Renault } \\
\text { Volvo Truck }\end{array}$ & & Development & & & & & CIGS & Aux. & [53] \\
\hline Truck & Navistar & Catalyst & $\begin{array}{l}\text { Proof of } \\
\text { concept }\end{array}$ & 2017 & & 22.4 & 3.64 & Silicon poly & Aux. & {$[54,55]$} \\
\hline Truck & $\begin{array}{c}\text { Daimler } \\
\text { FreightLiner }\end{array}$ & SuperTurck & $\begin{array}{l}\text { Proof of } \\
\text { concept }\end{array}$ & 2015 & & & & & Aux. & [56] \\
\hline Truck & $\begin{array}{l}\text { Mitsubishi } \\
\text { and Nippon }\end{array}$ & i Cool Solar & $\begin{array}{l}\text { Proof of } \\
\text { concept }\end{array}$ & 2010 & & & 0.9 & Organic/4.0\% & Aux. & [57] \\
\hline
\end{tabular}

Note: Prop., propulsion; Aux., powering accessories; Si, silicon; IBC, interdigitated back contact; HIT, heterojunction.

From the data gathered in Table 1, some key information was extracted and is detailed in Figures 2 and 3.

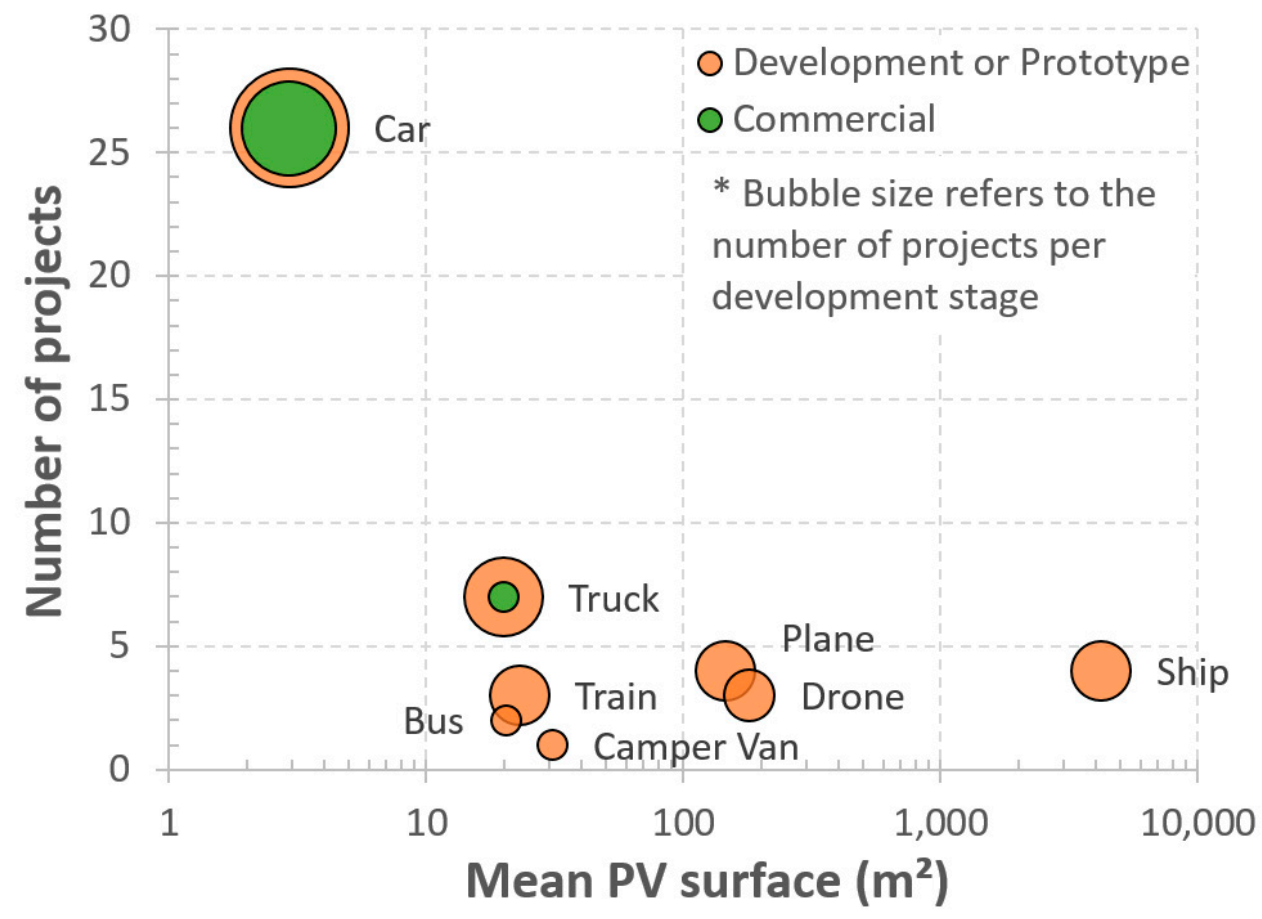

Figure 2. Number of initiatives for several vehicle types and their development stage.

Among the projects listed in Table 1, the majority are car-based (Figure 2). They are mainly proof-of-concept or development vehicles with integrated PV; however, a substantial number of market offerings can be found for cars (Figure 2).

According to the gathered data, the mean PV area for each kind of vehicle is significantly different (Figure 2). The mean embedded PV area ranges from $2.9 \mathrm{~m}^{2}$ for cars to thousands of square meters for ships. Note that, although passenger cars have the lowest available surface, they have still become the leading application of VIPV. The higher number of passenger cars on the market may explain the higher interest in integrating photovoltaics into passenger cars. The limited surface area raises the demand for high module power density and exploitation of highly curved surfaces. 


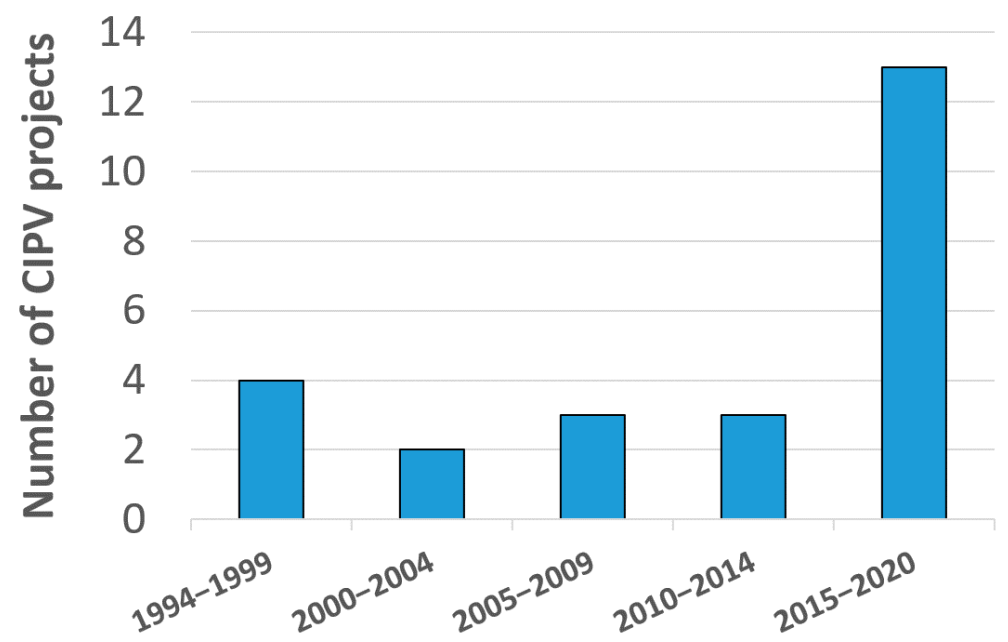

Figure 3. Number of CIPV projects over time.

Aspects such as module curvature and electrical module architecture (series or seriesparallel cells, number of bypass diodes, etc.), as well as vehicle system self-consumption, will lower the energy provided by PV during both parking and drive modes. Other aspects can impact the solar kilometers but not the energy provided as vehicle efficiency. The effects of added weight and changes in aerodynamic drag (if any) on the on-board photovoltaic should be considered when evaluating the energy and solar kilometers provided.

\subsubsection{Car-Integrated Photovoltaics and Constraints Related to the Automotive Sector}

It was found that the number of car-integrated photovoltaic (CIPV) projects has increased since 2015 (Figure 3). This increase may be linked to the reduction in PV price and increase in EV sales. Advantages such as increased range or lower recharge frequency, especially in summer, have led to a decrease in cost and increased market share.

For these developments, the following regulatory constraints are demanding [58-65]:

- The safety of the vehicle, verified through mechanical calculations, crash tests, static mechanical tests, impact, electrostatic discharge safety, and vibration or fatigue tests.

- Acoustic emissions, in order to limit noise pollution, particularly in cities. They can be limited by the choice of vibration-absorbing materials, the development of quieter engines, etc.

- Particle and greenhouse gas emissions, which can be reduced by developing fuelefficient engines and particle filters or even eliminated in the case of electric vehicles, at least during the vehicle's use phase [66].

- Recycling of the vehicle, with a recovery rate of $85 \%$ by weight, including a minimum recycling and reuse rate of $80 \%$ (European Directive on end-of-life vehicles (ELV); Directive 2000/53/EC of the European Parliament and of the Council of 18 September 2000).

In addition to these competitive and regulatory requirements, a car manufacturer must meet the following expectations of its end-users, which can be broken down according to different criteria:

- Safety: normally assured by standards, in addition to a feeling of safety. The interior must be protective, and the vehicle must be reliable in case of an accident. PV modules integrated in the roof and/or car body need to meet the relevant automotive safety standards.

- Reliability, robustness, durability: the purchase of a vehicle is an investment for 10 to 15 years [67]. It must remain in good condition in terms of performance and aesthetics without excessive maintenance throughout its life. If maintenance is required, it must be at an acceptable cost. 
- Purchase cost or lifetime profitability of the product: If the vehicle has a particular technology that increases the cost of the vehicle, it must have an important functionality for the user or pay back its cost in the long run. For example, for a solar panel, one could set a constraint that the additional cost of the technology should be translated into fuel savings, which would pay back the technology in a few years.

- Functionality: every user expects a product to fulfill certain functionalities. For example, for a photovoltaic module, the functionality is provided by the production of energy used either to propel the vehicle or to supply on-board equipment. We can also expect ease of use and a limitation of the constraints linked to its use (PV allows for example to reduce the time or the number of charging sessions on the grid, in addition to range extension). Another functionality could be the possibility to power auxiliary functions.

- Aesthetics for passenger cars similarly to building-integrated photovoltaics (BIPV) is critical although existing coloring technologies will reduce performance, leading to a tradeoff.

\subsubsection{Other Vehicles with On-Board PV}

Motor homes and coaches are often equipped with a PV module of about $100 \mathrm{Wp}$ to keep the lead-acid battery full for auxiliaries or to start the engine.

On coaches, trains, and trucks, $\mathrm{PV}$ is employed to power the auxiliaries even if no reason is given for this limitation. A few $\mathrm{kWp}$ of photovoltaics can be integrated on these vehicles where the mean PV area is about $20-23 \mathrm{~m}^{2}$. On vehicles, the commercial offers are mainly limited to installed PV kits.

Buses, drones, planes, and spatial vehicles have the largest available surface area for integrated PV, ranging from hundreds of square meters to even thousands of square meters on ships. The generated electricity is used for propulsion and/or auxiliaries, but no market offerings could be found.

The increased range offered by the photovoltaics embedded on a vehicle will depend heavily on the real energy generated by the PV, as well as on the vehicle performance in terms of system and motor efficiency, drag coefficient, weight, etc.

\subsection{Examination and Outlook of PV Technologies for PV-Powered Vehicles}

\subsubsection{Review of the PV Technologies and Their Performance}

A large number of PV cell concepts and technologies exist. The evolution of cell efficiency in research was presented by NREL [68].

GaAs single-junction cells and multijunction cells have the best efficiencies but also highest costs. Crystalline Si-based cells present a good reliability and the best compromise between performance and price. Thin-film technologies have lower efficiencies but a better flexibility and lower weight. Lastly, emerging PV technologies such as perovskite cells present high promise to simultaneously achieve high efficiency, low price, ultralow weight, and flexibility. Today, this technology still has limited trustworthiness, longevity, and yield compared to large-scale crystalline silicon cell-based modules (Figure 4).

The main commercial PV technologies are c-Si-based with PERx cells for example. The ITRPV 2021 roadmap estimated the market to be split across PERx/TOPCON, SHJ, IBC, and tandem cells in 2031 [70]. Interconnection technologies using cut cells have numerous advantageous for EV applications. The cells can embrace a curved shape. In addition, smaller cells allow higher parallel sections of cells in series to be established for the same module voltage. As the voltage follows a logarithmic relationship with the irradiance while the current is proportional to the irradiance, such architectures would help to reduce the impact of partial shadowing. A large number of main commercial PV modules are not adapted for integration into EVs as they are planar, nonflexible, and heavy [71]. 


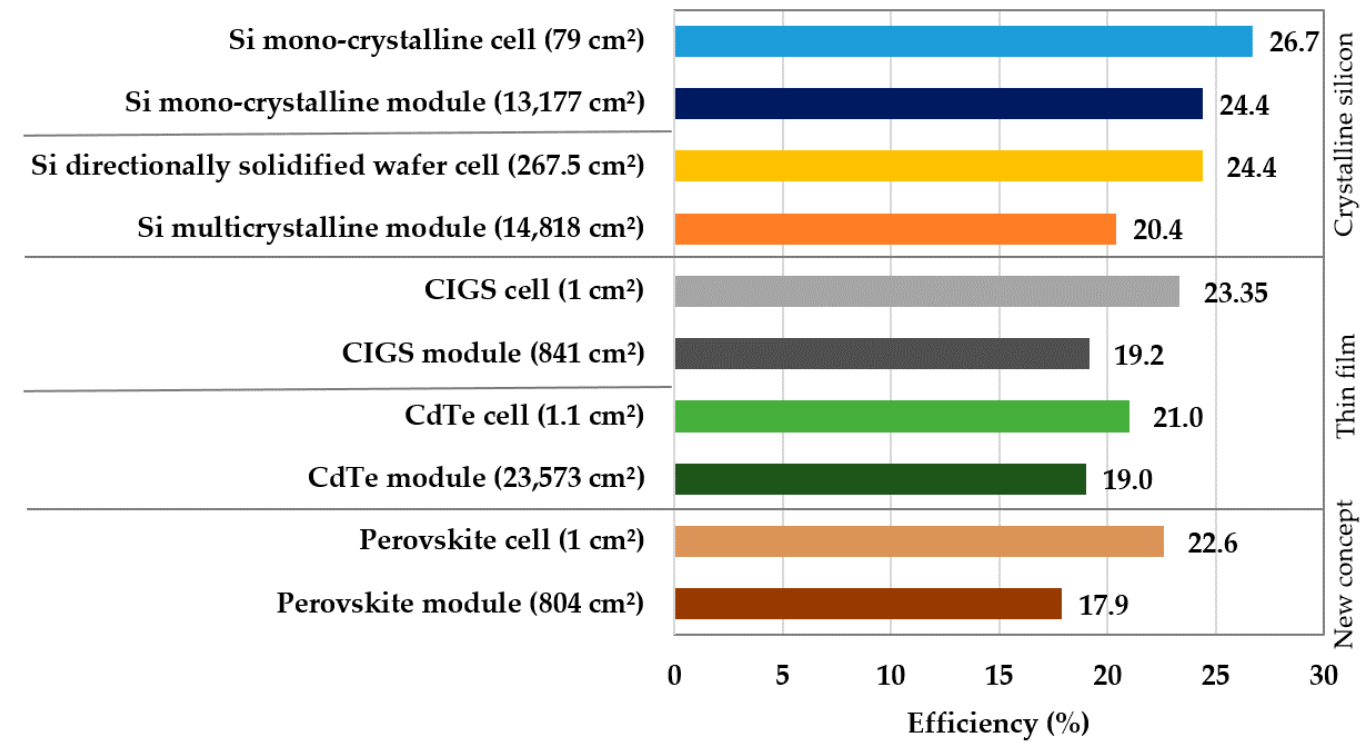

Figure 4. Best cell and module efficiencies found in the literature. Data from Green et al. [69].

2.2.2. Perspectives of the PV Technologies and Their Performance for Implementation in EVs

Different types of lightweight and/or flexible/curved PV modules already exist, including curved PV modules with a similar structure to a flat panel (2-3 mm thick front glass), flexible PV modules which are lightweight (often glass free), or light PV modules with a rigid structure. Examples of such PV technologies are presented in Figure 5. The characteristics of PV technologies vary depending on the application. Integration of the module-level electronics (usually bypass diodes or MOSFETs) into the module laminate could facilitate the placement of modules in/on EVs. An electrical architecture more resilient to shadowing is recommended for $\mathrm{EV}$ applications due to the higher frequency of partial shadowing compared to a power plant. One possibility is to increase the number of bypass diodes in a module of cells in series, whereas an alternative layout could include a parallel connection. Numerous solutions are under investigation for BIPV, which could inspire module design for EVs [72,73].

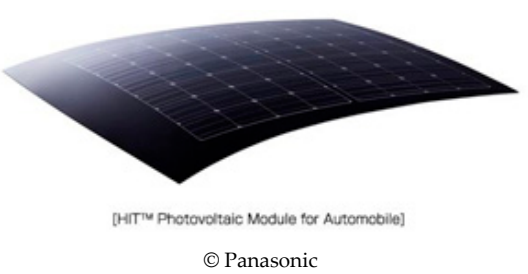

(a)

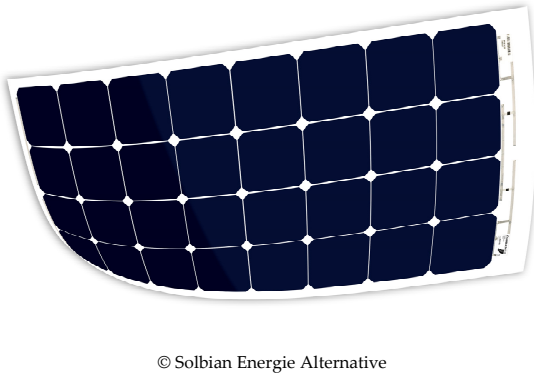

(b)

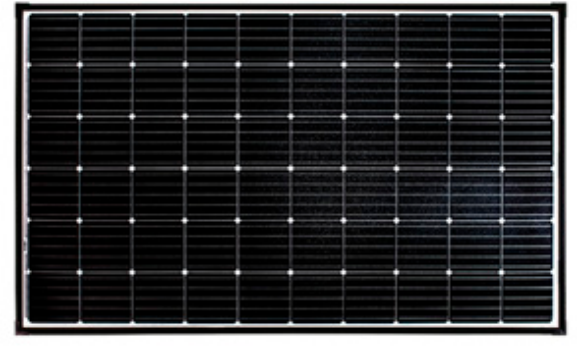

() Sunman Energy

(c)

Figure 5. (a) Curved Panasonic module for Toyota Prius [74]; (b) Solbian flexible solar panels [75]; (c) Sunman light solar panel [76].

A noncomprehensive list of commercially available low-weight and/or bendable modules is presented in Table 2, including information such as module yield, cell technology, weight, model, and manufacturer. 
Table 2. Non-comprehensive chart of light rigid and/or flexible PV technologies and their performances.

\begin{tabular}{|c|c|c|c|c|c|c|c|c|c|c|c|c|}
\hline Type & Manufacturer & $\begin{array}{l}\text { Model/ } \\
\text { Project }\end{array}$ & Stage & Year & $\begin{array}{l}\text { Cell Tech- } \\
\text { nology }\end{array}$ & $\begin{array}{l}\text { Cell Effi- } \\
\text { ciency }\end{array}$ & $\begin{array}{c}\text { Module } \\
\text { Efficiency }\end{array}$ & $\begin{array}{l}\text { P_Surf } \\
\mathrm{Wc} / \mathrm{m}^{2}\end{array}$ & $\begin{array}{l}\text { P_Mass } \\
\mathrm{Wc}_{\mathrm{c}} / \mathrm{kg}\end{array}$ & $\begin{array}{l}\text { Weight } \\
\mathrm{kg} / \mathrm{m}^{2}\end{array}$ & $\begin{array}{c}\text { Thickness } \\
\text { (mm) }\end{array}$ & References \\
\hline Curved & Panasonic & & $\begin{array}{l}\text { On the } \\
\text { market }\end{array}$ & 2017 & HIT & & & & & & & [74] \\
\hline Curved & A2Solar & & $\begin{array}{l}\text { On the } \\
\text { market }\end{array}$ & 2013 & Silicon & & & & & & & [77] \\
\hline Curved & Fuyao & & $\begin{array}{l}\text { On the } \\
\text { market }\end{array}$ & & & & & & & & & [78] \\
\hline Curved & Sunpower & & $\begin{array}{l}\text { On the } \\
\text { market }\end{array}$ & & Sunpower & & & & & & & [79] \\
\hline Curved & CEA / IPC & & Prototype & 2020 & $\begin{array}{l}\text { Silicon } \\
\text { mono }\end{array}$ & & & & & & & [80] \\
\hline Curved & LG & $\begin{array}{c}\text { Neon } 2 \\
\text { CELLO } \\
\text { cells } \\
(6 \times 9)\end{array}$ & Prototype & 2018 & $\begin{array}{l}\text { LG cell } \\
12 \mathrm{BB}\end{array}$ & $23.0 \%$ & & 167 & & & & {$[81,82]$} \\
\hline Curved & LG & $\begin{array}{l}\text { Neon R } \\
\text { IBC cells } \\
(6 \times 9)\end{array}$ & Prototype & 2018 & LG cell BC & $25.0 \%$ & & 193 & & & & {$[81,82]$} \\
\hline Curved & Fraunhofer & & Prototype & 2019 & $\begin{array}{c}366 \mathrm{Si} \\
\text { mono } \\
\text { shingle } \\
\text { cells }\end{array}$ & & & & & & & [83] \\
\hline $\begin{array}{l}\text { Flexible } \\
\text { PV }\end{array}$ & Gochermann & & $\begin{array}{l}\text { On the } \\
\text { market }\end{array}$ & 2014 & $\begin{array}{l}\text { Si mono } \\
\text { IBC }\end{array}$ & & $22.9 \%$ & 229 & 327 & 0.70 & & [84] \\
\hline $\begin{array}{l}\text { Flexible } \\
\text { PV }\end{array}$ & SinoSola & SASF & $\begin{array}{l}\text { On the } \\
\text { market }\end{array}$ & & $\begin{array}{l}\text { Si mono } \\
\text { IBC }\end{array}$ & $22.0 \%$ & $18.7 \%$ & 187 & 56 & 3.36 & 3.00 & [85] \\
\hline $\begin{array}{l}\text { Flexible } \\
\text { PV }\end{array}$ & Solbian & Flex SP & $\begin{array}{l}\text { On the } \\
\text { market }\end{array}$ & & $\begin{array}{l}\text { Si mono } \\
\text { IBC }\end{array}$ & $23.0 \%$ & $17.7 \%$ & 177 & 76 & 2.34 & 2.00 & [75] \\
\hline $\begin{array}{l}\text { Flexible } \\
\text { PV }\end{array}$ & Sacred Solar & & $\begin{array}{l}\text { On the } \\
\text { market }\end{array}$ & & $\begin{array}{l}\text { Si mono } \\
\text { IBC }\end{array}$ & $23.0 \%$ & $17.4 \%$ & 174 & 51 & 3.45 & 3.00 & [86] \\
\hline $\begin{array}{l}\text { Flexible } \\
\text { PV }\end{array}$ & DAS Energy & $\begin{array}{l}\text { Project } \\
\text { Series }\end{array}$ & $\begin{array}{l}\text { On the } \\
\text { market }\end{array}$ & 2017 & $\begin{array}{c}\text { Si mono } 5 \\
\text { BB }\end{array}$ & & $17.1 \%$ & 171 & 50 & 3.42 & 2.00 & [87] \\
\hline $\begin{array}{l}\text { Flexible } \\
\text { PV }\end{array}$ & HighFlex & HF315 & $\begin{array}{l}\text { On the } \\
\text { market }\end{array}$ & & $\begin{array}{c}\text { Si mono } 3 \\
\text { BB }\end{array}$ & $19.2 \%$ & $16.5 \%$ & 165 & 88 & 1.89 & 1.50 & [88] \\
\hline $\begin{array}{l}\text { Flexible } \\
\text { PV }\end{array}$ & Armor & ASCA & $\begin{array}{l}\text { On the } \\
\text { market }\end{array}$ & & Organic & & & & & & & [89] \\
\hline $\begin{array}{l}\text { Flexible } \\
\text { PV }\end{array}$ & Heliatek & HeliaSol & $\begin{array}{l}\text { On the } \\
\text { market }\end{array}$ & & Organic & & & & & & & [90] \\
\hline $\begin{array}{l}\text { Flexible } \\
\text { PV }\end{array}$ & Opvius & & $\begin{array}{l}\text { On the } \\
\text { market }\end{array}$ & & Organic & & & & & & & [91] \\
\hline $\begin{array}{l}\text { Flexible } \\
\text { PV }\end{array}$ & $\begin{array}{l}\text { Hanergy } \\
\text { Miasolé }\end{array}$ & 02WS & $\begin{array}{l}\text { On the } \\
\text { market }\end{array}$ & 2018 & CiGS & $17.0 \%$ & $15.1 \%$ & 151 & 56 & 2.69 & 2.50 & [92] \\
\hline $\begin{array}{l}\text { Flexible } \\
\text { PV }\end{array}$ & $\begin{array}{l}\text { Sunport } \\
\text { Power }\end{array}$ & S-FLEX & $\begin{array}{l}\text { On the } \\
\text { market }\end{array}$ & & $\begin{array}{c}\text { Silicon } \\
\text { mono }\end{array}$ & & $20.1 \%$ & 201 & 61.1 & 3.29 & 2.5 & [93] \\
\hline $\begin{array}{l}\text { Flexible } \\
\text { PV }\end{array}$ & Sunware & 20 series & $\begin{array}{l}\text { On the } \\
\text { market }\end{array}$ & 2017 & $\begin{array}{l}\text { Silicon } \\
\text { mono }\end{array}$ & & $14.3 \%$ & 143 & 21 & 6.74 & 5.00 & [94] \\
\hline $\begin{array}{l}\text { Flexible } \\
\text { PV }\end{array}$ & Nanosolar & UltraLight & $\begin{array}{l}\text { On the } \\
\text { market }\end{array}$ & & CiGs & $11.7 \%$ & $11.2 \%$ & 112 & 43 & 2.56 & 4.00 & [95] \\
\hline $\begin{array}{l}\text { Flexible } \\
\text { PV }\end{array}$ & Flisom & eFlex 3.1 & $\begin{array}{l}\text { On the } \\
\text { market }\end{array}$ & & CiGS & & $9.4 \%$ & 94 & 36 & 2.59 & 2.20 & [96] \\
\hline $\begin{array}{l}\text { Flexible } \\
\text { PV }\end{array}$ & Couleenergy & & $\begin{array}{l}\text { On the } \\
\text { market }\end{array}$ & & $\begin{array}{l}\text { Si mono } \\
\text { shingle }\end{array}$ & $22.4 \%$ & $17.7 \%$ & 177 & 70 & 2.53 & & [97] \\
\hline $\begin{array}{l}\text { Flexible } \\
\text { PV }\end{array}$ & $\begin{array}{l}\text { Energy } \\
\text { Mobile }\end{array}$ & & $\begin{array}{l}\text { On the } \\
\text { market }\end{array}$ & & $\begin{array}{l}\text { Silicon } \\
\text { mono IBC }\end{array}$ & & $18.3 \%$ & 183 & 43 & 4.31 & 3.00 & [98] \\
\hline $\begin{array}{l}\text { Flexible } \\
\text { PV }\end{array}$ & Go Power & $\begin{array}{l}\text { Solar } \\
\text { Flex }\end{array}$ & $\begin{array}{l}\text { On the } \\
\text { market }\end{array}$ & & & & & & & & & [99] \\
\hline $\begin{array}{l}\text { Flexible } \\
\text { PV }\end{array}$ & Ocean Vital & & $\begin{array}{l}\text { On the } \\
\text { market }\end{array}$ & & & & & & & 1.60 & $0.8-1.5$ & [100] \\
\hline $\begin{array}{l}\text { Light } \\
\text { rigid PV }\end{array}$ & BenQ Solar & & $\begin{array}{l}\text { On the } \\
\text { market }\end{array}$ & & $\begin{array}{l}\text { Silicon } \\
\text { mono }\end{array}$ & & $16.5 \%$ & 165 & 27 & 6.00 & & [101] \\
\hline $\begin{array}{l}\text { Light } \\
\text { rigid PV }\end{array}$ & Sunman & $\begin{array}{l}\text { eArche } \\
325\end{array}$ & $\begin{array}{l}\text { On the } \\
\text { market }\end{array}$ & 2017 & $\begin{array}{c}\text { Si mono } 4 \\
\text { BB }\end{array}$ & & $16.1 \%$ & 161 & 42 & 3.82 & 5.60 & [76] \\
\hline $\begin{array}{l}\text { Light } \\
\text { rigid PV }\end{array}$ & Solarge & $\begin{array}{l}\text { Solarge } \\
\text { DUO }\end{array}$ & $\begin{array}{l}\text { On the } \\
\text { market }\end{array}$ & 2022 & $\begin{array}{l}\text { Silicon } \\
\text { mono }\end{array}$ & & $18.9 \%$ & 189 & 34 & 5.48 & 14 & [102] \\
\hline $\begin{array}{l}\text { Light } \\
\text { rigid PV }\end{array}$ & SBM Solar & & $\begin{array}{l}\text { On the } \\
\text { market }\end{array}$ & & & & & 160 & 19 & 8.30 & & [103] \\
\hline $\begin{array}{l}\text { Oight } \\
\text { rigid PV }\end{array}$ & Fujipream & Nozomi & $\begin{array}{l}\text { On the } \\
\text { market }\end{array}$ & & & & & & & 6.50 & & [104] \\
\hline $\begin{array}{l}\text { Light } \\
\text { rigid PV }\end{array}$ & Tulipps Solar & & $\begin{array}{l}\text { On the } \\
\text { market }\end{array}$ & & & & & & & 8.50 & & [105] \\
\hline
\end{tabular}

Among the projects listed in Table 2, 50\% are flexible PV modules (Figure 6), representing the most active module technology. As flexible modules can be added to existing vehicles (e.g., the roof), in addition to other applications with limited added weight, they represent one of the fastest ways to integrate photovoltaics. On the other hand, curved photovoltaic modules with a $2-3 \mathrm{~mm}$ thick glass cover have significant added weight compare to the metal roof. This may explain the lower number of projects listed. Cur- 
rently, light rigid photovoltaic modules are mainly flat panels, whereas 3D curved ones are in development.

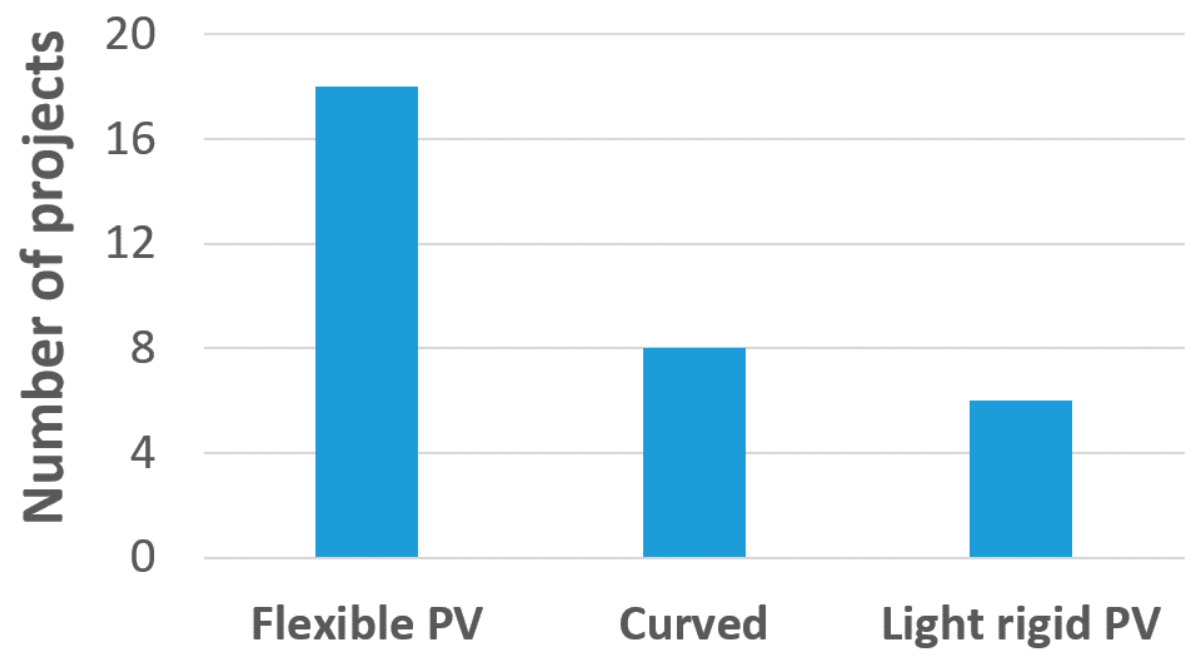

Figure 6. Number of projects for each type module technology.

\subsubsection{Curved Photovoltaic Technologies}

Glass-backsheet or glass-glass arched photovoltaic modules have a similar structure to standard PV panels with a thick front glass cover of 2.0 to $3.2 \mathrm{~mm}$. This architecture utilizes 3D curved glass and, as listed in Table 2, commercial offers are available [74,77-82].

\subsubsection{Bendable Photovoltaic Technologies}

Bendable photovoltaic modules employ a variety of different technologies, from crystalline silicon-based cells to thin-film technologies such as CIGS solar cells or organic films (Table 2). These modules are flexible and low-weight $\left(0.7\right.$ to $6.7 \mathrm{~kg} / \mathrm{m}^{2}$, see Figure 7) compared with the $11 \mathrm{~kg} / \mathrm{m}^{2}$ of a standard glass-backsheet module. Their power density varies widely due to the diversity of cell technologies used; however, module efficiencies close to standard flat modules exist (Figure 7), and there are commercial offers available.

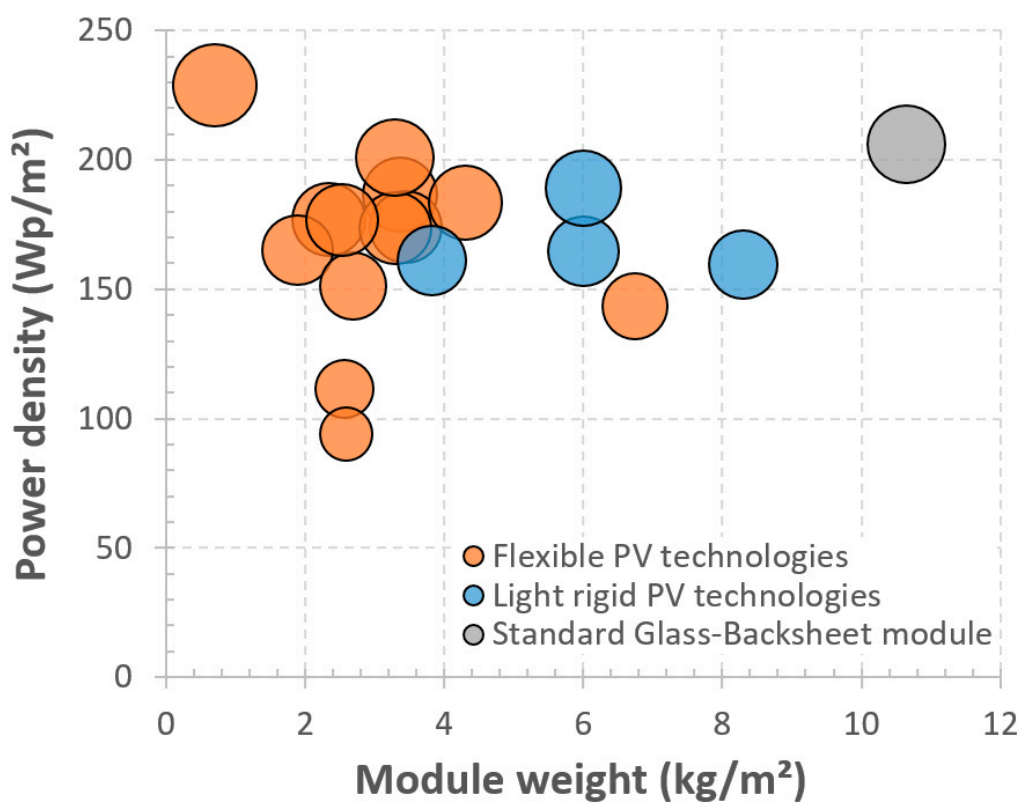

Figure 7. Number of flexible and light (nonflexible) modules in Table 2 (commercial brands) and their weight, where each bubble is a product. The flexible modules do not include the typical $6 \mathrm{~kg} / \mathrm{m}^{2}$ metal sheet of the car body. 


\subsubsection{Light Rigid PV Technologies}

Nonflexible but light and rigid PV module technologies are listed in Table 2. Such modules are not flexible, but they may replace the body parts of a vehicle. They also have the potential to be $3 \mathrm{D}$ curved. Commercial offers are available with module weights often between 5.6 and $8.9 \mathrm{~kg} / \mathrm{m}^{2}$ but also down to $\leq 4 \mathrm{~kg} / \mathrm{m}^{2}$ (Figure 7).

Curved PV technologies using composite parts instead of glass for lighter technologies are under development.

\section{Conclusions}

Our review clearly highlights the rapid development of VIPV for passenger cars, with a large fraction of technologies at the prototype stage. Commercial offers within this product category clearly represent the pioneers of the sector.

Although early prototypes explored the use of high-efficiency cells, silicon-based photovoltaics is currently the dominant technology presenting an optimal tradeoff across performance, price, and reliability. Their drawback is their poor pliability in bidirectional flexion, limiting design options.

Longer-term perovskite-based photovoltaics will have the potential of combining high efficiency, low cost, and flexibility after 2023 according to ITRPV 2021.

Glass-glass and glass-backsheet curved PV modules are currently the most common technology in VIPV despite their higher weight $\left(>11 \mathrm{~kg} / \mathrm{m}^{2}\right)$ and lack of aesthetics. However, its similarity to standard flat PV modules ensures the availability of qualified materials and, hence, higher reliability and durability potential.

Flexible PV module technologies have the advantage of a lower weight (0.7 to $6.7 \mathrm{~kg} / \mathrm{m}^{2}$ ), with power densities close to standard flat PV modules. Additionally, this technology is suitable for both new and aftersales market by adding PV modules to existing vehicle parts. We anticipate that the rapid development of dedicated module materials for flexible panels and their qualification in both standard PV and VIPV applications will lead to their increasing market share. We anticipate that these technologies will form the second generation of VIPV modules.

Ultimately, light and rigid PV modules represent the most promising technology as they have the potential to replace the body parts of a vehicle. This technology has the potential of a lighter weight balance on the vehicle level thanks to full integration compared to flexible added PV functionality. For example, the development of light and curved PV modules using composite materials is in progress [80].

\section{Perspectives}

VIPV development will also need to meet other challenges not discussed here, such as energy production forecast, energy management, low environmental impact, and recycling.

The forecasting of PV production for a typical year is possible through tools such as PVGIS [106] of PVSYST [107]. The mean annual energy is, thus, pretty well known and helps the development of photovoltaics. On-board photovoltaics in vehicles usually involve curved PV modules, and the vehicles are, by definition, at different locations, as well as both static and non-static. The mean annual energy production also depends on the use cases, and there is a lack of data available for both irradiance and associated products.

The optimal energy harvesting of photovoltaic requires day-long operation. This situation may imply a significant energy loss from the vehicle system that is required to be partially awake. The optimization of vehicle system energy consumption may, thus, be a significant way to improve on-board photovoltaics. Additionally, cases with more system energy consumption than production must be avoided, for example, via a system shut down.

Other promising applications of EVs, including PHEV, are V2X (vehicle-to-everything) applications, such as vehicle-to-home [108], V2V (vehicle-to-vehicle), V2B (vehicle-tobuilding), or V2G (vehicle-to-grid). Such functionalities allow using the photovoltaic 
energy generated in homes and others, which is beneficial for the photovoltaic energy utilization ratio.

A need for new standards has to be highlighted. To the best of the authors' knowledge, the measurement of curved PV modules is not yet addressed by existing standards [4]. It might be more relevant to indicate a calculated power label value from a mixture of measurements at different angles of incidence using direct/diffuse light. Indeed, curved modules can be more sensitive to changes in yield depending on the angle of irradiance and the use of direct or diffuse sunshine.

Standards do exist for photovoltaic modules in automotive applications; however, to the best of the authors' knowledge, they are neither dedicated to on-board PV application nor ensure the compatibility of requirements of both domain standards.

A third point is the need for a standardized calculation of the energy produced. Moreover, in the case of the energy being used for solar kilometers, their calculation requires a standard approach.

Finally, calculation of the impact of $\mathrm{CO}_{2}$ emissions from on-board vehicle-integrated $\mathrm{PV}$, such as HEV or PHEV, needs to be fully defined and approved as an eco-innovation [2].

Author Contributions: Investigation, V.M.; writing—original draft preparation, B.C.; writing—review and editing, T.D. and J.G.; supervision, F.C. and E.V. All authors have read and agreed to the published version of the manuscript.

Funding: This research received funding from ADEME, grant number 1905C0043. This project was realized with the participation from members of INES.2S and received funding from the French State under its investment for the future program with reference ANR-10-IEED-0014-01.

Institutional Review Board Statement: Not applicable.

Informed Consent Statement: Not applicable.

Data Availability Statement: Not applicable.

Conflicts of Interest: The authors declare no conflict of interest. The funders had no role in the design of the study; in the collection, analyses, or interpretation of data; in the writing of the manuscript, or in the decision to publish the results.

\section{References}

1. Potential and Challenges of Vehicle Integrated Photovoltaics for Passenger Cars. Available online: https://www.researchgate. net/publication/346393294_Potential_and_Challenges_of_Vehicle_Integrated_Photovoltaics_for_Passenger_Cars (accessed on 15 July 2021).

2. Cabuzel, T. $\mathrm{CO}_{2}$ Emission Performance Standards for Cars and Vans. Available online: https://ec.europa.eu/clima/policies/ transport/vehicles/regulation_en (accessed on 6 September 2021).

3. ETIP PV Publishes New Position Paper on VIPV as a Core Source for Electricity in Road Transport-Other News-ETIP PV. Available online: https: / / etip-pv.eu/news/other-news/etip-pv-publishes-new-position-paper-on-vipv-as-a-core-source-forelectricity-in-road-transport/ (accessed on 15 July 2021).

4. Araki, K.; Ji, L.; Kelly, G.; Yamaguchi, M. To do list for research and development and international standardization to achieve the goal of running a majority of electric vehicles on solar energy. Coatings 2018, 8, 251. [CrossRef]

5. Le Solaire, une énergie d'avenir. Available online: https://www.fr.sunpower.com/fr/etudes-de-cas/le-solaire-une-energiedavenir (accessed on 6 May 2020).

6. Sion Electric Car-Sono Motors. Available online: https://sonomotors.com/en/sion/ (accessed on 5 May 2020).

7. Toyota Prius Hybride Rechargeable Découvrez La Brochure. Available online: https://www.toyota.fr/new-cars/prius-plugin/ brochure (accessed on 5 May 2020).

8. Clément DETHLEFFS Lève le Voile sur L'E-home, un Concept 100\% électrique. Available online: https:/ /www.campingcarlesite. com/camping-car-neuf/2320-dethleffs-leve-le-voile-sur-l-e-home-un-concept-100-electrique/ (accessed on 6 May 2020).

9. La SNCF Teste des Trains Economes en Energie. Available online: https://www.latribune.fr/green-business/1-actualite/106574 3/la-sncf-teste-des-trains-economes-en-energie.html (accessed on 5 May 2020).

10. Starter Hybride Solaire: Brillant Avenir En Vendée! Available online: https: / / www.fccbus.fr/actualites.php?news=21 (accessed on 5 May 2020).

11. Renault Trucks Corporate-Les Communiqués: Optifuel Lab 2: L'excellence Énergétique de Renault Trucks. Available online: https:/ / corporate.renault-trucks.com/fr/les-communiques/optifuel-lab-2-l-excellence-energetique-de-renault-trucks.html (accessed on 5 May 2020). 
12. Solar Powered Trucks. Available online: https://tsscgroup.com/products-and-services/truck-bodies-semi-trailers/solarpowered-trucks / (accessed on 5 May 2020).

13. Perrier, V. Un Bateau Photovoltaïque. Available online: http://conseilsolaire.online/bateau-photovoltaique (accessed on 6 May 2020).

14. Atlantiksolar. Available online: http://www.atlantiksolar.ethz.ch/ (accessed on 5 May 2020).

15. Solar Impulse Foundation: 1000 Profitable Solutions for the Environment. Available online: https://solarimpulse.com/ (accessed on 5 May 2020).

16. Eraole: L'avion Hybride de Demain. Available online: https://www.sciencesetavenir.fr/high-tech/transports/eraole-l-avionhybride-de-demain_111543 (accessed on 5 May 2020).

17. Space Q\&A: Stratobus I Drupal. Available online: https://www.thalesgroup.com/fr/worldwide/espace/magazine/space-qastratobus (accessed on 5 May 2020).

18. Ecoship. Available online: http:/ / ecoship-pb.com/ (accessed on 6 May 2020).

19. Energy Observer. Available online: http://www.cea.fr/multimedia/Documents/infographies/energy-observer.pdf (accessed on 5 May 2020).

20. Solar Electric Catamaran. Available online: https:/ / soelyachts.com/soelcat-12/ (accessed on 5 May 2020).

21. Dethleffs e.Home: Le Camping-Car 100\% Électrique Est Arrivé-Le Monde Du Camping Car. Available online: https:/ /www. lemondeducampingcar.fr/actualite/camping-car / dethleffs-e-home-le-camping-car-100-lectrique-est-arriv / 60626 (accessed on 5 May 2020).

22. 2020 Hyundai Sonata Hybrid: What to Expect from Its Mpg-Boosting Solar Roof. Available online: https:/ /www.greencarreports. com/news/1127957_2020-hyundai-sonata-hybrid-what-to-expect-from-its-mpg-boosting-solar-roof (accessed on 5 May 2020).

23. Everything about the Sonata Hybrid's Solar Roof-Hyundai Motor Group TECH. Available online: https:/ / tech.hyundaimotorgroup. com/article/everything-about-the-sonata-hybrids-solar-roof/ (accessed on 5 May 2020).

24. A2Solar Potentiel of Solar Systems in Vehicles for Air Conditioning. Available online: https://www.autoklimaanlage. info/fileadmin/user_upload/Tagung_2013/PRO_KLIMA_Wecker_Potentials_of_Solar_Systems_in_Vehicles_for_Air_ Conditioning_2013-12-04.pdf (accessed on 5 May 2020).

25. [Hot Item] Energy Saved Solar Electric Car Populr Vehicles. Available online: https://gaiasolar.en.made-in-china.com/product/ ASuQJdZbZPpO/China-Energy-Saved-Solar-Electric-Car-Populr-Vehicles.html (accessed on 5 May 2020).

26. 2014 Nissan Leaf Press Kit. Available online: https://usa.nissannews.com/en-US/releases/us-2014-nissan-leaf-press-kit (accessed on 5 May 2020).

27. Kia and Hyundai Reveal Solar Charging System Technology to Power Future Eco-Friendly Vehicles. Available online: https: //press.kia.com/ie/en/home/media-resouces/press-releases/2018/Kia_and_Hyundai_reveal_solar_charging_system.html (accessed on 5 May 2020).

28. Lambert, F. Hyundai and Kia Unveil New Solar Roof to Charge Batteries in Vehicles, Launching next Year. Available online: https:/ / electrek.co/2018/10/31/hyundai-kia-solar-roof-electric-vehicles/ (accessed on 5 May 2020).

29. Lambert, F. Tesla Cybertruck Will Have Solar Roof Option to Add 15 Miles of Range per Day. Available online: https:/ / electrek. co/2019/11/22/tesla-cybertruck-solar-roof-option-add-range/ (accessed on 6 May 2020).

30. Une Voiture à l'énergie Solaire Chez Fiat? Available online: https:/ / www.autoplus.fr/actualite/make-Divers-model-Divers-65 9700.html (accessed on 6 May 2020).

31. Fiat: Le Projet Phylla en Panne? Non, Seulement Sur une Dépanneuse. Available online: https://blogautomobile.fr/fiat-le-projetphylla-en-panne-non-seulement-sur-une-depanneuse-19272 (accessed on 6 May 2020).

32. Toyota Shows off Solar Prius with 860 W Output from 34\% Efficient Cells. Available online: https://www.pv-magazine.com/20 19/07/12/toyota-shows-off-solar-prius-with-860-w-output-from-34-efficient-cells/ (accessed on 5 May 2020).

33. Solar Car Tarp to Recharge EV Batteries-Pv Magazine International. Available online: https://www.pv-magazine.com/2020/0 4/06/solar-car-tarp-to-recharge-ev-batteries / (accessed on 5 May 2020).

34. Retractable Car Cover Claimed to Gain Miles of EV Range Each Day. Available online: https://www.greencarreports.com/news/ 1127787_retractable-car-cover-claimed-to-gain-miles-of-ev-range-each-day (accessed on 5 May 2020).

35. Hanergy Solar R. Available online: https://www.allcarindex.com/concept/china/hanergy/solar-r/ (accessed on 5 May 2020).

36. China's Hanergy Showcases 4 Models of 100\% Solar Cars. Available online: / news/chinas-hanergy-showcases-4-models-of-100solar-cars-531316/ (accessed on 5 May 2020).

37. Ford C-Max Solar Energi: La Première Vraie Voiture Solaire? Automobile. Available online: https://www.lepoint.fr/automobile/ innovations / ford-c-max-solar-energi-la-premiere-vraie-voiture-solaire-03-01-2014-1776499_652.php (accessed on 6 May 2020).

38. Home-BO SolarCar. Available online: https:/ /www.bosolarcar.de/ (accessed on 6 May 2020).

39. Vehicles Sunswift. Available online: http://sunswift.com/vehicles (accessed on 5 May 2020).

40. Salon EVER: Venturi Présente 1' Eclectic, une Voiture électrique Autonome. Available online: https:/ / www.cnetfrance.fr/cartech/ salon-ever-venturi-presente-1-eclectic-une-voiture-electrique-autonome-39368366.htm (accessed on 5 May 2020).

41. Solar Car Roof by A2-Solar. Available online: https://a2-solar.com/en/vw-tiguan-gte-concept-iaa-2015/ (accessed on 5 May 2020).

42. ISRO Demonstrates Solar Hybrid Electric Car. Available online: https://www.carandbike.com/news/isro-demonstrates-solarhybrid-electric-car-1688371 (accessed on 6 May 2020). 
43. Peugeot: Le BB1 électrique Fait sa Promo Européenne-Enerzine. Available online: https://www.enerzine.com/peugeot-le-bb1 -electrique-fait-sa-promo-europeenne/9355-2009-11 (accessed on 6 May 2020).

44. Gibbs, Y. NASA Dryden Fact Sheet-Helios Prototype. Available online: http://www.nasa.gov/centers/armstrong/news/ FactSheets/FS-068-DFRC.html (accessed on 6 May 2020).

45. Zephyr. Available online: https://www.airbus.com/defence/uav/zephyr.html (accessed on 5 May 2020).

46. L' Avion-SolarStratos. Available online: https://www.solarstratos.com/plane/ (accessed on 5 May 2020).

47. Premier Vol Historique Pour L'avion Hybride Eraole-YouTube. Available online: https:/ / www.youtube.com/watch?v=MeTi2 u3kkdc (accessed on 5 May 2020).

48. Solar Ship I No Roads. No Fuel. No Infrastructure. Available online: http:/ /cn.solarship.com/ (accessed on 7 October 2021).

49. Flixbus Dote Ses Bus de Panneaux CIGS Ayant Une Efficacité de 18\%. Available online: https:/ / www.pv-magazine.fr/2020/02/ 14/flixbus-dote-ses-bus-de-panneaux-cigs-ayant-une-efficacite-de-18/ (accessed on 13 May 2020).

50. Mondialisation, M. Un Premier «Train Solaire» en Inde: Entre Rêve de Transition et Limites. Available online: https:// mrmondialisation.org/un-premier-train-solaire-en-inde/ (accessed on 6 May 2020).

51. «Byron Bay Train» Sustainability. Available online: https:/ / byronbaytrain.com.au/sustainability/ (accessed on 3 November 2020)

52. SuperTruck Volvo Trucks USA. Available online: https://www.volvotrucks.us/innovation/supertruck/ (accessed on 5 May 2020).

53. Transports. Available online: https:/ / www.solar-cloth.fr/transports/ (accessed on 4 November 2020).

54. International's CataLIST SuperTruck: The Features. Available online: https:/ /www.ccjdigital.com/international-catalist-supertruck/ (accessed on 5 May 2020).

55. Lockridge, D. How Fleets are Using Solar Power. Available online: https://www.truckinginfo.com/157690/how-fleets-areusing-solar-power (accessed on 5 May 2020).

56. SuperTruck. Available online: https:// freightliner.com/why-freightliner/industry-leading-results/supertruck/ (accessed on 6 May 2020).

57. macsworldwide I-Cool Solar System Tested in Japan. Available online: https://macsworldwide.wordpress.com/2010/11/16/icool-solar-system-tested-in-japan/ (accessed on 6 May 2020).

58. Full-Width-Frontal-Impact-Test-Protocol-V102.Pdf. Available online: https://cdn.euroncap.com/media/20872/full-widthfrontal-impact-test-protocol-v102.pdf (accessed on 6 September 2021).

59. Euro NCAP. Available online: https:/ / cdn.euroncap.com/media/41747/euro-ncap-mpdb-testing-protocol-v10.20181106152012 1613.pdf (accessed on 6 September 2021).

60. FMVSS No. 216a, Roof Cruch Resistance. Available online: https://www.nhtsa.gov/sites/nhtsa.gov/files/tp-216a-00.pdf (accessed on 6 September 2021).

61. Sabale, M.S.; Vivekanandan, N.; Kulkarni, S.S. Design and Analysis of Automotive Roof by Using Modern Materials Forms Like Plastics as an Effective Alternative. Available online: https://www.technicaljournalsonline.com/ijaers/VOL\%20III/IJAERS\%20 VOL\%20III\%20ISSUE\%20IV\%20JULY\%20SEPTEMBER\%202014/491.pdf (accessed on 6 September 2021).

62. Automotive Standards Overview-ASTM International. Available online: https://www.astm.org/industry/automotiveoverview.html (accessed on 6 September 2021).

63. Stratton, D.; Platte, P.; Rocco, D. A Modular Automotive Roof System Design Concept Based on Polyurethane Composite Technology. Available online: http:/ /www.temp.speautomotive.com/SPEA_CD/SPEA2006/PDF/e/e1.pdf (accessed on 6 September 2021).

64. EUR-Lex-L21225-EN_EUR-Lex. Available online: https://eur-lex.europa.eu/legal-content/FR/TXT/?uri=legissum\%3A12 1225 (accessed on 6 September 2021).

65. Directive 2000/53/CE Du Parlement Européen et Du Conseil Du 18 Septembre 2000 Relative Aux Véhicules Hors D'usage-Déclarations de La Commission. Available online: https://www.legifrance.gouv.fr/jorf/id/JORFTEXT000000518580 (accessed on 6 September 2021).

66. EU Economy and Society to Meet Climate Ambitions. Available online: https://ec.europa.eu/commission/presscorner/detail/ en/IP_21_3541 (accessed on 2 September 2021).

67. L'industrie Automobile Française-Analyse et Statistiques 2019. Available online: https://ccfa.fr/wp-content/uploads/2019/0 9/ccfa-2019-fr-web-v2.pdf (accessed on 11 August 2020).

68. Best Research-Cell Efficiency Chart. Available online: https:/ /www.nrel.gov / pv / cell-efficiency.html (accessed on 29 May 2020).

69. Green, M.A.; Dunlop, E.D.; Hohl-Ebinger, J.; Yoshita, M.; Kopidakis, N.; Hao, X. Solar cell efficiency tables (Version 58). Prog. Photovolt. Res. Appl. 2021, 29, 657-667. [CrossRef]

70. ITRPV Roadmap. Available online: https://itrpv.vdma.org:443/viewer/-/v2article/render/29775594 (accessed on 19 July 2021).

71. Photovoltaics Report. Available online: https://www.ise.fraunhofer.de/content/dam/ise/de/documents/publications/studies/ Photovoltaics-Report.pdf (accessed on 13 May 2020).

72. Calcabrini, A.; Muttillo, M.; Weegink, R.; Manganiello, P.; Zeman, M.; Isabella, O. A fully reconfigurable series-parallel photovoltaic module for higher energy yields in urban environments. Renew. Energy 2021, 179, 1-11. [CrossRef] 
73. Götz, D.; Hahn, D.; Gottschalg, R.; Daßler, D.; Schindler, S.; Hanifi, H. Evaluation of Shading Tolerance of PV Modules with Different Module Designs for Mobile Application by Simulation, Indoor and Outdoor Measurements. 2019. Available online: https://www.researchgate.net/profile/Hamed-Hanifi/publication/336738157_EVALUATION_OF_ SHADING_TOLERANCE_OF_PV_MODULES_WITH_DIFFERENT_MODULE_DESIGNS_FOR_MOBILE_APPLICATION_ BY_SIMULATION_INDOOR_AND_OUTDOOR_MEASUREMENTS/links/5db0069f4585155e27f7f8db/EVALUATION-OFSHADING-TOLERANCE-OF-PV-MODULES-WITH-DIFFERENT-MODULE-DESIGNS-FOR-MOBILE-APPLICATION-BYSIMULATION-INDOOR-AND-OUTDOOR-MEASUREMENTS.pdf (accessed on 13 May 2020).

74. Panasonic's Photovoltaic Module HIT(TM) Adopted for Toyota Motor's New Prius PHV Headquarters News. Available online: http:/ / news.panasonic.com/global/press/data/2017/02/en170228-3/en170228-3.html (accessed on 6 May 2020).

75. SP Series—Solbian. Available online: https://www.solbian.eu/en/5-sp-series (accessed on 6 May 2020).

76. SUNMAN. Available online: http://www.sunman-energy.com/pro_38_show.html (accessed on 7 May 2020).

77. A2-Solar-Advanced and Automotive Solar Systems for Facades, Vehicles and Special Applications. Available online: https: / / a2-solar.com/en/ (accessed on 7 May 2020).

78. Photovoltaic Sunroof_Fuyao Group. Available online: https://www.fuyaogroup.com/en/products_list_14.html (accessed on 6 May 2020).

79. Panneaux Solaires Pour Applications Résidentielles et Tertiaires SunPower France. Available online: https://www.fr.sunpower. $\mathrm{com} / \mathrm{fr}$ (accessed on 7 May 2020).

80. Duigou, T.; Boichon, V.; Brancaz, X.; Chabuel, F.; Francescato, P.; Gaume, J.; Habchi, G.; Lagache, M.; Saffre, P.; Tenchine, L. VIPV: Process Development of Integrated Photovoltaic Cells in a Double-Curved Composite Structure for Automotive Application. In Proceedings of the 37th European Photovoltaic Solar Energy Conference and Exhibition, Online, 7-12 September 2020; pp. 1787-1790. [CrossRef]

81. Solar Panels for Retailers and Installers LG Solar. Available online: http://www.lg-solar.com/hu/media/news/news-2018_aug. jsp (accessed on 5 May 2020).

82. LG Solar Panels and Battery Systems 2019. Available online: https://www.cleanenergyreviews.info/blog/lg-solar-home-essbattery-system (accessed on 5 May 2020).

83. Fraunhofer ISE Displays Colored Solar Car Roof at Auto Trade Fair. Available online: https://www.pv-magazine.com/2019/09/ 03/fraunhofer-ise-displays-colored-solar-car-roof-at-auto-trade-fair/ (accessed on 6 May 2020).

84. Gochermann Solar Technology-Development and Production of High Performance Solar Arrays. Available online: https: //www.gochermann.com/ (accessed on 6 May 2020).

85. Sinosola. Available online: http:/ / www.sinosola.cn/ (accessed on 7 May 2020).

86. High Efficiency Bendable PV Module-Sacred Industry I Sacred Solar Technology I Sacred New Energy. Available online: http: / / www.sacredsolar.com/index.aspx?menuid=12\&type=introduct\&lanmuid=26\&language=en (accessed on 6 May 2020).

87. DAS Energy. Available online: https:/ / www.das-energy.com (accessed on 6 May 2020).

88. HighFlexSolar. Available online: https:/ / www.highflexsolar.com/ (accessed on 6 May 2020).

89. ASCA®. Film Photovoltaïque Organique Transparent et Souple. Available online: https://www.asca.com/ (accessed on 11 May 2020).

90. Heliatek Global Leader for Organic Solar Films. Available online: https:/ /www.heliatek.com/ (accessed on 11 May 2020).

91. Home-Organic Photovoltaic Solutions. Available online: http://www.opvius.com/ (accessed on 11 May 2020).

92. SolarRide Transportation Solution-Miasole. Available online: http:/ / miasole.com/products / (accessed on 8 July 2020).

93. Solar Module Mwt Solar Cell PV Module Manufacturer. Available online: https://www.sunportpower.com/ (accessed on 19 July 2021).

94. SunWare Series-20. Available online: https://en.sunware.solar/produkte/module_folie_20xxx (accessed on 6 May 2020).

95. Nanosolar. Available online: http:/ / www.nanosolar.com/ (accessed on 6 May 2020).

96. EMetal, ERoll, EFlex \& Customization / Flisom. Available online: https:/ /www.flisom.com/products / (accessed on 6 May 2020).

97. IEC61215 \& IEC61730 Certified Solar Panels. Available online: https:/ / couleenergy.com/ (accessed on 6 May 2020).

98. Panneau Solaire Flexible, Electricité Autonome-Energie Mobile. Available online: http://www.energiemobile.com/ (accessed on 6 May 2020).

99. Solar Flex Kits. Available online: https:/ / gpelectric.com/product-category/solar/solar-flex-kits-solar/ (accessed on 6 May 2020).

100. Fondation Océan Vital. Available online: https://agence-api.ouest-france.fr/societe/fondation-ocaan-vital (accessed on 6 May 2020).

101. AUO Solar. Available online: https: / / solar.auo.com/fr-FR (accessed on 7 May 2020).

102. Solar Module for East-West Installations on Flat Rooftops. Available online: https://www.pv-magazine.com/2021/09/07/solarmodule-for-east-west-installations-on-flat-rooftops / (accessed on 20 September 2021).

103. SBM Solar. Available online: https:/ / sbmsolar.com (accessed on 7 May 2020).

104. Solar Photovoltaic System I Fuji Pream Corporation. Available online: http://www.fujipream.co.jp/en/tech/tech2/ (accessed on 7 May 2020).

105. TULiPPS—Home. Available online: https://www.tulipps.com/nl (accessed on 7 May 2020).

106. JRC Photovoltaic Geographical Information System (PVGIS)—European Commission. Available online: https://re.jrc.ec.europa. eu/pvg_tools/fr/tools.html (accessed on 29 October 2021). 
107. PVSYST. Available online: https:/ / www.pvsyst.com/fr/ (accessed on 29 October 2021).

108. Tostado-Véliz, M.; León-Japa, R.S.; Jurado, F. Optimal electrification of off-grid smart homes considering flexible demand and vehicle-to-home capabilities. Appl. Energy 2021, 298, 117184. [CrossRef] 